Case Reports
in Dermatology
Case Rep Dermatol 2020;12:266-274

DOI: $10.1159 / 000509764$

Published online: December 2, 2020
(C) 2020 The Author(s)

Published by S. Karger AG, Basel www.karger.com/cde

This article is licensed under the Creative Commons Attribution-NonCommercial 4.0 International License (CC BY-NC) (http://www.karger.com/Services/OpenAccessLicense). Usage and distribution for commercial purposes requires written permission.

\author{
Single Case
}

\title{
Don't Judge a Tumor by Its Biopsy!
}

\author{
Mia Demant Iselin Saltvig Hannah Trøstrup Volker J. Schmidt \\ Jørgen Hesselfeldt
}

Department of Plastic Surgery and Breast Surgery, Zealand University Hospital, Roskilde, Denmark

\section{Keywords}

Trichoblastoma $\cdot$ Basal cell carcinoma $\cdot$ Clinical assessment $\cdot$ Punch biopsy

\begin{abstract}
Trichoblastomas (TBs) are extremely rare, benign hair germ tumors that can mimic basal cell carcinoma (BCC). They usually arise on the head or neck and have a potential for malignant transformation, albeit it is rare. We report a case of giant TB on the forehead of a 75 -year-old otherwise healthy woman. Since the age of 20 she reported a bulge on her forehead, in which a superficial-looking wound had now developed. Initially a dermatologist biopsied the tumor suspecting a BCC, which the histological analyses confirmed. The patient was then referred to the Department of Plastic Surgery for complete excision of the carcinoma, including the large frontal bulge. Surprisingly, the concluding pathology report changed the diagnosis from a BCC to a TB. Current management of most skin lesions relies on the histopathological subtype of a single punch biopsy. Many benign and malignant dermatological entities may mimic BCC, and therefore misdiagnosis can lead to either unnecessary excision or delayed treatment of metastatic disease. Mimics may include various types of nonneoplastic processes, benign adnexal tumors, including $\mathrm{TB}$, or cutaneous carcinomas with basaloid features. A single punch biopsy is not always adequate in making the correct diagnosis. Although it is considered the gold
\end{abstract}




\section{Case Reports in Dermatology}

Case Rep Dermatol 2020;12:266-274

DOI: $10.1159 / 000509764$

(c) 2020 The Author(s). Published by S. Karger AG, Basel www.karger.com/cde

Demant et al.: Don't Judge a Tumor by Its Biopsy!

standard, the clinical assessment is just as important. Due to its potential for malignant transformation, it is recommended to excise TB with negative margins.

(C) 2020 The Author(s)

Published by S. Karger AG, Basel

\section{Introduction}

Cutaneous adnexal tumors cover a large group of mostly benign neoplasms. Trichoblastoma (TB) is a rare, mesenchymal-epithelial tumor arising from rudimentary hair follicles, usually on the head or neck. Macroscopically, TB appears typically as a skin-colored, exo- and endophytic nodule without ulceration, may range up to $8 \mathrm{~cm}$ in diameter, and is defined as "giant TB" when $>2 \mathrm{~cm}$. Microscopically, TB typically lacks epidermal connection and presents as a symmetrical neoplasm composed of monomorphous basaloid cells with follicular germs, fibrillary stroma, and papillae.

Another nonadnexal tumor of the skin is basal cell carcinoma (BCC), which is the most common malignant neoplasm with an estimated overall lifetime risk of $30 \%$; it is also the most frequently encountered diagnosis in dermatopathology [1]. Clinically, dermoscopically, and histopathologically, the differentiation between TB and BCC can be challenging.

With this case report we want to emphasize the importance of taking all the above aspects into consideration in the assessment of skin tumors and delineate the similarities and differences between TBs and BCCs.

\section{Case Presentation}

A 75-year-old woman went to the doctor because she had noted a persistent lump on her central forehead that had grown considerably in size during the last couple of years (Fig. 1,2). The lump had supposedly been present following a bicycle trauma with forehead involvement at the age of 20. Superiorly on the lump, an erythematous swelling with central ulceration had developed, and she was referred to a dermatologist, suspecting a BCC. The dermatologist assessed the underlying tumor as being completely benign with an obvious nodular BCC on top. Punch biopsy from the ulcerated area revealed a BCC of nodular type, made up of basaloid cells, palisading along the edge, and a surrounding desmoplastic reaction (Fig. 3). No vascular or nerve invasion was present. She was then referred to the Department of Plastic Surgery for excision of both the BCC and the underlying probably benign tumor. The underlying tumor was macroscopically assumed to be a lipoma of $30 \times 20 \times 15 \mathrm{~mm}$ with a BCC on top that amounted to $13 \mathrm{~mm}$ in diameter. Fusiform excision of both elements including a 5 -mm surgical margin was performed.

Surprisingly, the final pathology report described a tumor solely compatible with giant TB, and not enough convincing evidence of the previously mentioned BCC could be seen. Due to the remaining TB cells present in all of the outer edges, the pathologist recommended an additional small excision to ensure radicality, which was performed accordingly and which revealed clear surgical margins. Six months following surgery, the patient was still well with no clinical signs of relapse. 


\section{Case Reports in Dermatology}

Case Rep Dermatol 2020;12:266-274

DOI: $10.1159 / 000509764$

(C) 2020 The Author(s). Published by S. Karger AG, Basel www.karger.com/cde

Demant et al.: Don't Judge a Tumor by Its Biopsy!

\section{Discussion}

Headington [2] introduced the name "trichoblastoma" in 1970 and divided neoplasms of the hair germ into TBs, trichogenic TBs, trichogenic myxomas, and trichoblastic fibromas, based on their degree of stromal induction. In 1993, Ackerman et al. [3] published a new classification of the neoplasms of the hair germ. They described TBs as benign tumors with a sharp circumscription, vertical orientation, smooth borders, and symmetrical growth, and trichoepitheliomas as a superficial type of TBs with a cribriform growth pattern. As formerly mentioned, giant TBs are rare, and the previously reported cases are listed in Table 1 [4-16].

BCCs are composed of cells with large, elongated nuclei that display palisading at the edge of tumor nodules. Usually mitoses and single-cell apoptoses are present, and their cytoplasms can be pale, lightly eosinophilic, or inconspicuous. They display characteristic clefting between the stroma and the tumor edge and are associated with a myxoinflammatory stroma that contains different degrees of mucin and lymphocytic inflammation [1]. BCCs exhibit several patterns of growth and can be broadly divided into aggressive (including micronodular, infiltrative, morpheaform, and metatypical) and indolent (nodular and superficial) types. Combinations of growth patterns are present in $40-75 \%$ of all BCC specimens $[16,17]$. Moreover, when comparing punch biopsies to complete excisions, an intrinsic error rate of approximately $20 \%$ in determining the correct BCC subtype classification exists. BCCs express a profile of cytokeratin similar to that of follicular germinative cells characterized by CK5/6, CK14, and the absence of CK20 [16].

In challenging cases, immunohistochemical stains can be helpful in differentiating between TBs and BCCs. CK20 is seen on benign Merkel cells, which often colonize TBs, and the androgen receptor is often seen on BCCs, but no single marker appears completely sensitive or specific for this distinction [1]. In Table 2 we have listed certain similarities and differences between TBs and BCCs $[1,18]$.

In the present case, the final pathology report described a neoplasia built up of multinodular units separated by thin collagen strokes. The neoplastic cells were basaloid with a follicular germinal imprint and some palisading and occasional mitoses. Central factors that pointed towards a giant TB were its well-defined and dermal location without relation to the epidermis and the lack of desmoplastic stroma, together with the immune profile with CK20 (Fig. 4).

\section{Conclusion}

Both the clinical appearance and the histopathological analysis must be taken into account in clinical assessment. A single punch biopsy might not always be adequate in making the correct diagnosis. Although it is considered the gold standard and a powerful tool, the clinical assessment can be just as important. Therefore, we suggest taking several biopsies from larger indefinite tumors prior to surgery for accuracy. With this case report, we wish to strengthen the reader's attention to TBs, and despite their rarity, it is important to be able to distinguish them from BCCs. Due to their potential for malignant transformation, it is recommended to excise benign TBs with negative margins. 


\section{Acknowledgments}

We thank our colleagues from the Department of Pathology, Zealand University Hospital, who provided their expertise in tissue analysis, including microscopic examination and immunohistochemistry.

\section{Statement of Ethics}

This research was conducted ethically in accordance with the World Medical Association Declaration of Helsinki. The patient gave written informed consent for publication of her case (including publication of images).

\section{Conflict of Interest Statement}

The authors have no conflicts of interest to declare.

\section{Funding Sources}

No funding was received.

\section{Author Contributions}

M. Demant: study consent, design, data collection, interpretation, writing of the paper. I. Saltvig, H. Trøstrup, V.J. Schmidt, and J. Hesselfeldt: design, interpretation, writing of the paper.

\section{References}

1 Stanoszek LM, Wang GY, Harms PW. Histologic Mimics of Basal Cell Carcinoma. Arch Pathol Lab Med. 2017 Nov;141(11):1490-502.

2 Headington JT. Differentiating neoplasms of hair germ. J Clin Pathol. 1970 Sep;23(6):464-71.

3 Ackerman A, de Viragh P, Chongchitnant N. Neoplasms with follicular differentiation. Philadelphia: Lea \& Febiger; 1993. p. 359-420.

4 Frings VG, Goebeler M, Kneitz H. Dermpath \& Clinic: giant trichoblastoma of the leg. Eur J Dermatol. 2017 Aug;27(4):447-8.

5 Lee JS, Kwon JH, Jung GS, Lee JW, Yang JD, Chung HY, et al. A giant trichoblastic carcinoma. Arch Craniofac Surg. 2018 Dec;19(4):275-8.

6 Nguyen LV, Masouminia M, Choy JO, Peng SK, Ji P, French SW. Atypical giant trichoblastoma: an unusual presentation. Exp Mol Pathol. 2017 Feb;102(1):22-4.

7 Benaïm G, Castillo C, Houang M, Dejardin L, Mateus C, Wang Q, et al. Melanoma arising from a long-standing pigmented trichoblastoma: clinicopathologic study with complementary aCGH/mutational analysis. Am J Dermatopathol. 2014 Aug;36(8):e146-51. 


\section{Case Reports in Dermatology}

8 Landolsi A, Khaled A, Bougacha L, Helali H, Kourda N, Fazaa B, et al. Giant trichoblastoma of the scalp. Tunis Med. 2011 Jun;89(6):569-72.

9 Krishnamurthy J, Divya K. The cytology of giant solitary trichoepithelioma. J Cytol. 2010 Jul;27(3):99-101.

10 Kim HJ, Lee HK, Cho JH, Yang HJ. Quantitative comparison of transient elastography (TE), shear wave elastography (SWE) and liver biopsy results of patients with chronic liver disease. J Phys Ther Sci. 2015 Aug;27(8):2465-8.

11 Morillo V, Manrique P, Vildósola S, Saiz A, Artola JL, Bilbao I. Giant trichoblastoma. Actas Dermosifiliogr. 2006 Sep;97(7):467-9. Spanish.

12 Takai T, Tsuji M, Ueda M. Two cases of subcutaneous trichoblastoma. J Dermatol. 2004 Mar;31(3):232-5.

13 Cheng L, Binder SW, Gajjar NA, Hirschowitz SL. Fine-needle aspiration biopsy as an adjunct to the diagnosis of a rare adnexal tumor of hair follicle origin: trichoblastoma. Diagn Cytopathol. 2003 Oct;29(4):225-8.

14 Ohnishi T, Watanabe S. Immunohistochemical analysis of cytokeratin expression in various trichogenic tumors. Am J Dermatopathol. 1999 Aug;21(4):337-43.

15 Requena L, Barat A. Giant trichoblastoma on the scalp. Am J Dermatopathol. 1993 Oct;15(5):497-502.

16 Russell EB, Carrington PR, Smoller BR. Basal cell carcinoma: a comparison of shave biopsy versus punch biopsy techniques in subtype diagnosis. J Am Acad Dermatol. 1999 Jul;41(1):69-71.

17 Sexton M, Jones DB, Maloney ME. Histologic pattern analysis of basal cell carcinoma. Study of a series of 1039 consecutive neoplasms. J Am Acad Dermatol. 1990 Dec;23(6 Pt 1):1118-26.

18 Alsaad KO, Obaidat NA, Ghazarian D. Skin adnexal neoplasms - part 1: an approach to tumours of the pilosebaceous unit. J Clin Pathol. 2007 Feb;60(2):129-44.

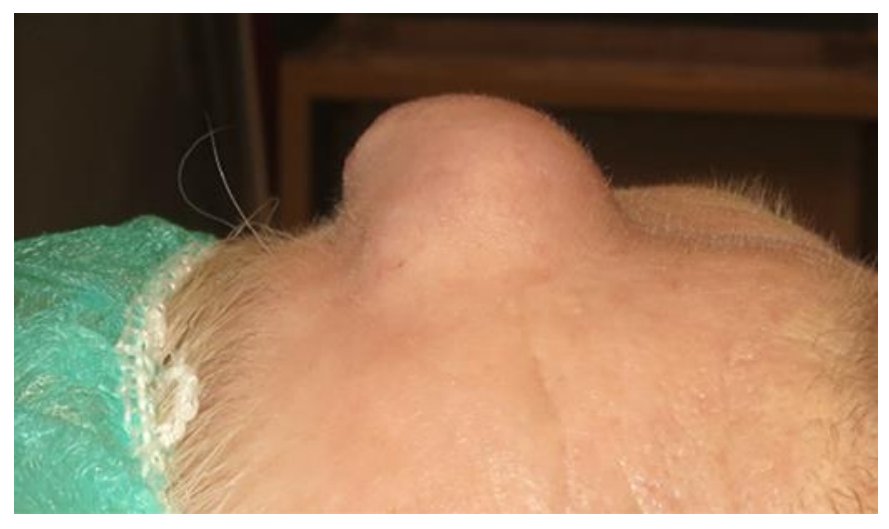

Fig. 1. Lateral view of the trichoblastoma. 


\section{Case Reports in Dermatology}

Case Rep Dermatol 2020;12:266-274 (c) 2020 The Author(s). Published by S. Karger AG, Basel www.karger.com/cde

Demant et al.: Don't Judge a Tumor by Its Biopsy!

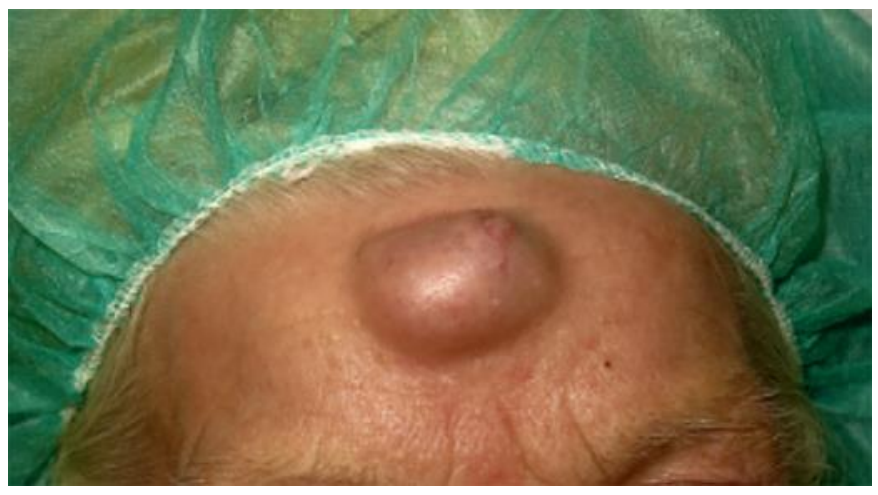

Fig. 2. Anterior view of the trichoblastoma.

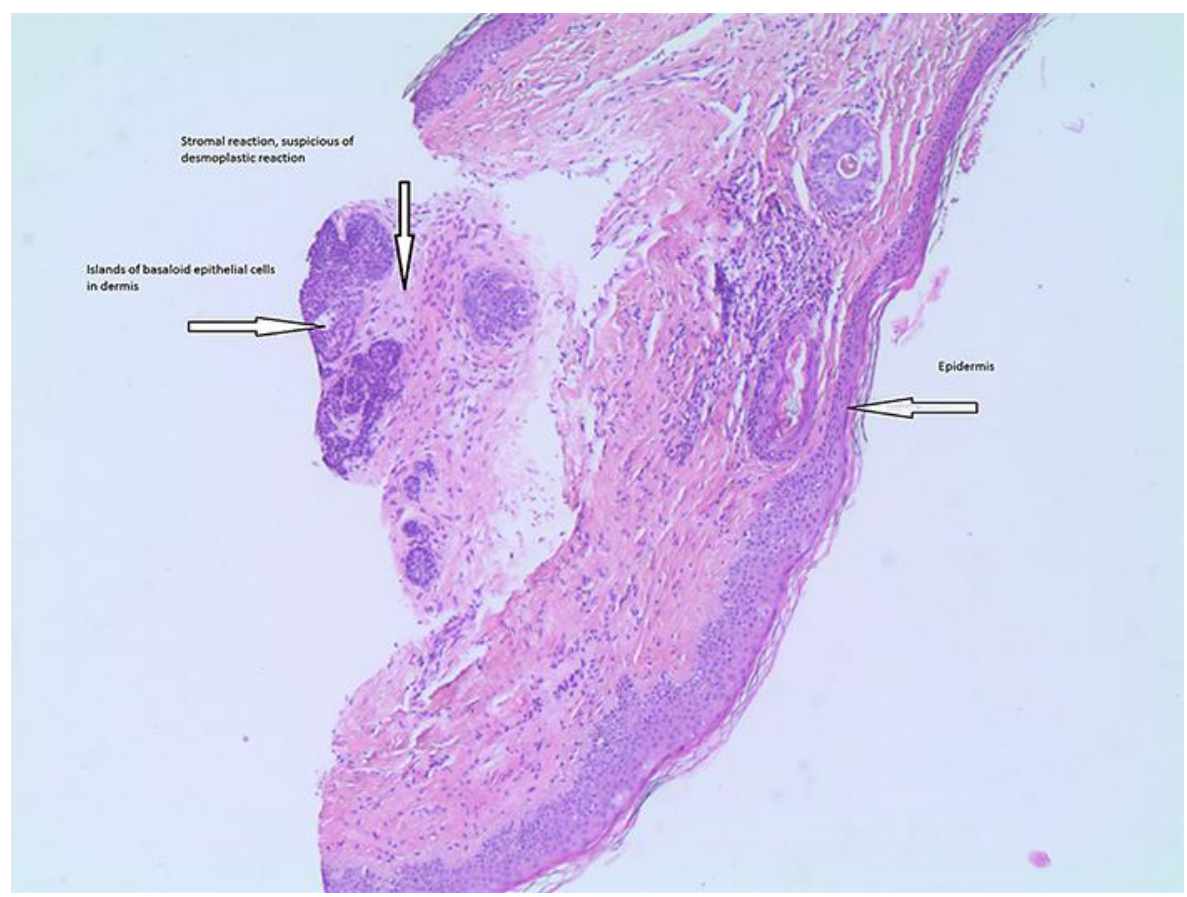

Fig. 3. Initial punch biopsy. Basaloid epithelial cells in the dermis and stromal reaction. Hematoxylin-eosin, $\times 5$. 


\section{Case Reports in Dermatology}

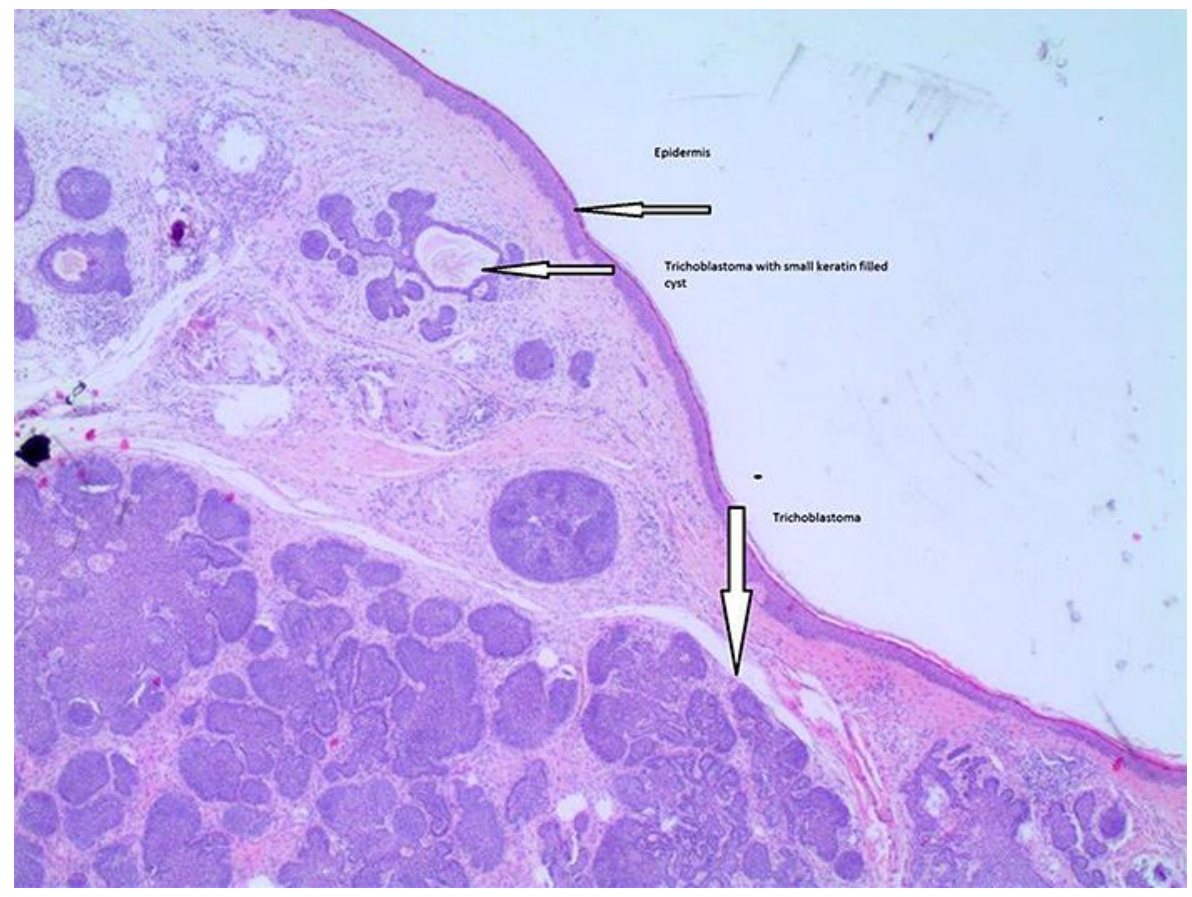

Fig. 4. Excision of a well-circumscribed tumor with islands of basaloid epithelial cells, no connection to the epidermis, and dermis with minimal stromal reaction. Hematoxylin-eosin, $\times 2.5$. 


\section{Case Reports in Dermatology}

Case Rep Dermatol 2020;12:266-274 (c) 2020 The Author(s). Published by S. Karger AG, Basel www.karger.com/cde

Demant et al.: Don't Judge a Tumor by Its Biopsy!

Table 1. Previously reported cases of giant TB

\begin{tabular}{|c|c|c|c|c|c|c|c|c|c|}
\hline $\begin{array}{l}\text { Reference } \\
\text { (first author) }\end{array}$ & $\begin{array}{l}\text { Age, } \\
\text { sex }\end{array}$ & $\begin{array}{l}\text { Duration } \\
\text { of history }\end{array}$ & $\begin{array}{l}\text { Tumor } \\
\text { size, cm }\end{array}$ & Location & Histological findings & $\begin{array}{l}\text { Immunohistochemical } \\
\text { findings }\end{array}$ & Final diagnosis & Treatment & Outcome \\
\hline Frings, 2017 [4] & $77, \mathrm{M}$ & 10 years & 5 & $\begin{array}{l}\text { upper leg, } \\
\text { dermis }\end{array}$ & $\begin{array}{l}\text { PP, clefts and dense FS, keratin } \\
\text { cysts }\end{array}$ & $\begin{array}{l}\text { Ber-EP4, Ki67, CD10 + } \\
\text { EMA - }\end{array}$ & giant TB & excision & NR \\
\hline Lee, 2018 [5] & $25, \mathrm{M}$ & $\begin{array}{l}\text { since birth; } \\
\text { excised } 3 \text { times } \\
\text { before }\end{array}$ & 9 & $\begin{array}{l}\text { nuchal area, } \\
\text { dermis }\end{array}$ & $\begin{array}{l}\text { basaloid proliferation, } \mathrm{OM} \text {, } \\
\text { infiltrative tumor composed of } \\
\text { neoplastic cells }\end{array}$ & cytokeratin, p53, Ki67 + & $\begin{array}{l}\text { giant TB } \\
\text { differentiated into } \\
\text { trichoblastic } \\
\text { carcinoma }\end{array}$ & excision & NR \\
\hline Nguyen, 2017 [6] & $49, \mathrm{M}$ & 1 year & 5.5 & $\begin{array}{l}\text { lateral thigh, } \\
\text { dermis }\end{array}$ & BCs, dense FS, OM, clefts & $\begin{array}{l}\text { keratin, Ber-EP4, CD10 + } \\
\text { EMA, CK7, vimentin - }\end{array}$ & giant TB & excision & NR \\
\hline Benaïm, 2014 [7] & $62, \mathrm{M}$ & 50 years & 8 & flank, dermis & $\begin{array}{l}\text { large epithelial BCs with rare } \\
\text { pigmented cells and dendritic } \\
\text { melanocytes }\end{array}$ & $\begin{array}{l}\text { S100 protein, MelanA, } \\
\text { HMB45, MiTF, } \\
\text { pancytokeratin, AE1/AE3, } \\
\text { KL1 + }\end{array}$ & $\begin{array}{l}\text { malignant melanoma } \\
\text { arising from a giant } \\
\text { pigmented TB }\end{array}$ & excision & $\begin{array}{l}\text { died of } \\
\text { metastatic } \\
\text { disease } 8 \text { months } \\
\text { after initial } \\
\text { diagnosis }\end{array}$ \\
\hline $\begin{array}{l}\text { Krishnamurthy, } \\
2010 \text { [9] }\end{array}$ & $80, \mathrm{M}$ & 1 year & 3 & nose, dermis & uniform BCs, FS & ND & giant solitary TB & $\begin{array}{l}\text { excision } \\
\text { biopsy }\end{array}$ & ND \\
\hline Kim, 2015 [10] & $57, \mathrm{M}$ & 5 years & 6 & back, dermis & $\begin{array}{l}\text { BCs with scanty cytoplasm, } \\
\text { dendritic melanocytes }\end{array}$ & $\begin{array}{l}\text { Bcl-2, CK20, MelanA, S100 } \\
\text { protein, HMB45 + }\end{array}$ & $\begin{array}{l}\text { melanotricho- } \\
\text { blastoma }\end{array}$ & excision & ND \\
\hline Morillo, 2006 [11] & $71, \mathrm{~F}$ & 2 years & 6 & $\begin{array}{l}\text { buttock, } \\
\text { dermis }\end{array}$ & PP, OM, dense FS & ND & giant TB & excision & ND \\
\hline Takai, 2004 [12] & $54, \mathrm{~F}$ & ND & 3 & $\begin{array}{l}\text { scalp, } \\
\text { subcutis }\end{array}$ & $\begin{array}{l}\text { FGC, mitoses -, keratinous } \\
\text { cysts, BCs, FS }\end{array}$ & ND & giant TB & excision & NR \\
\hline Takai, 2004 [12] & $53, \mathrm{~F}$ & 6 months & 1 & $\begin{array}{l}\text { left shin, } \\
\text { subcutis }\end{array}$ & $\begin{array}{l}\text { FGC, mitoses -, keratinous } \\
\text { cysts, BCs, FS }\end{array}$ & ND & TB & excision & NR \\
\hline Cheng, 2003 [13] & $81, \mathrm{~F}$ & 5 years & 8.5 & back, dermis & $\begin{array}{l}\text { PP, BCs, papillary } \\
\text { mesenchymal bodies, OM }\end{array}$ & ND & giant TB & excision & ND \\
\hline $\begin{array}{l}\text { Requena, } 1993 \\
{[15]}\end{array}$ & $69, \mathrm{M}$ & many years & $>3$ & scalp, dermis & PP, FGC & ND & giant TB & excision & ND \\
\hline $\begin{array}{l}\text { Russell, } 1999 \\
{[16]}\end{array}$ & $73, \mathrm{M}$ & 60 years & 10 & $\begin{array}{l}\text { upper arm, } \\
\text { deep dermis }\end{array}$ & $\begin{array}{l}\text { BCs, FS, concentric } \\
\text { keratinization, abortive hair } \\
\text { papilla }\end{array}$ & ND & giant TB & excision & ND \\
\hline
\end{tabular}

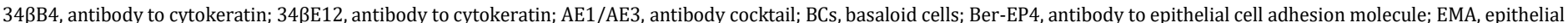

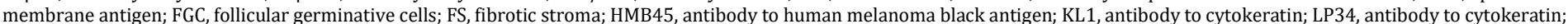

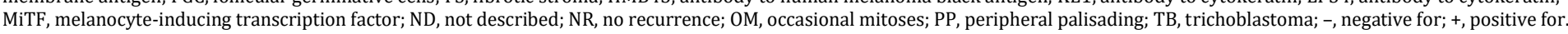


Case Reports
in Dermatology

Case Rep Dermatol 2020;12:266-274

DOI: $10.1159 / 000509764$

(C) 2020 The Author(s). Published by S. Karger AG, Base www.karger.com/cde

Demant et al.: Don't Judge a Tumor by Its Biopsy!

Table 2. Similarities and differences between TB and BCC

\begin{tabular}{lll}
\hline Feature & TB & BCC \\
\hline $\begin{array}{l}\text { Epidemiology } \\
\text { Age }\end{array}$ & younger & older \\
Site & occurs anywhere & occurs sun-exposed areas \\
Location & within deep dermis and subcutaneous fat & within dermis \\
\hline Histology & & sclerotic and normal amount \\
Stroma & sclerotic and minimal amount & yes \\
Peripheral palisading & yes & no \\
Keratin cysts & yes & rarely \\
Follicular papillae & yes & yes \\
Calcification & yes & \\
\hline Immunohistochemistry & & no \\
CK20 & yes, on colonizing benign Merkel cells & often \\
Androgen receptor & no & no \\
CD10 & yes & \\
\hline
\end{tabular}

BCC, basal cell carcinoma; CK, cytokeratin; TB, trichoblastoma. 